\title{
ON THE STATUS OF THE COLLOSPHAERID RADIOLARIAN SPECIES SIPHONOSPHAERA BRACHYSIPHONIA DUMITRICĂ, 1978 AND SIPHONOSPHAERA ARKYS SU, 1982
}

\author{
Paulian Dumitrică
}

Received: 26 February 2019 / Accepted: 26 March 2019 / Published online: 1 April 2019

\begin{abstract}
The article demonstrates that the collosphaerid radiolarian species Siphonosphaera arkys Su, 1982 from the Quaternary of China is a junior synonym of Siphonosphaera brachysiphonia Dumitrică, 1978, described from the late Middle Miocene Radiolarian Shale Formation from the Getic Depression, Romania. This species is re-illustrated with additional photos at optical microscope and drawings to a better understanding of its morphology.
\end{abstract}

Keywords: Polycystine Radiolaria, Collosphaeridae, Siphonosphaera, synonymy.

\section{INTRODUCTION}

This short article is part of the preparing work of a catalogue of Cenozoic radiolarian genera and families started in 2012 under the authorship of Jean-Pierre Caulet (France), Luis O’Dogherty (Spain), Paulian Dumitrică (Romania \& Switzerland), and Noritoshi Suzuki (Japan), and expected to be published this year as a monograph in Geodiversitas, as the previous two volumes, one on the Mesozoic genera, the other one on the Paleozoic genera (Caulet et al, 2017).

The former species mentioned in the title has been published by Dumitrică (1978b) in a paper included in the volume on the Badenian from the series of volumes consecrated to the stratigraphy of Paratethys. As a contributor of this volume with two articles I was obliged to restrict as much as possible the number of printing pages. The result is that the descriptions of new taxa were very short, the necessary information on them very reduced and the number of figures and plates very small. To this, one can add that the quality of images are not always very good. All these make the recognition of some species difficult. That is why I felt obliged to republish some of such species. Siphonosphaera brachysiphonia is one of them.

Siphonosphaera brachysiphonia was first described as a new species in 1974 in an unpublished scientific report of the Geological Institute of Romania together with other species from the Radiolarian Shale Formation and published four years later (Dumitrică, 1974, 1978b). In that report all species have been illustrated with both photographs at optical microscope and drawings. All these photos and especially drawings of the present species included in that report are reproduced in the present note to show the variability of the species and to give a better image of its shell.

Taxonomy.

Class RADIOLARIA Müller, 1858

Subclass Polycystina Ehrenberg, 1875

Order Collodaria Haeckel, 1881

Family Collosphaeridae Müller, 1858
Genus Siphonosphaera Müller, 1858

Type species: Siphonosphaera tubulosa Müller, 1858

Siphonosphaera brachysiphonia Dumitrică, 1978

Figs. 1a-h

1978b Siphonosphaera brachysiphonia Dumitrică nov. sp., p. 235, pl. 5, fig. 1.

1982 Siphonosphaera arkys Su nov. sp., p. 276, pl. 2, figs. 3,4 .

1990 Collosphaerid sp. A - Abelmann, p. 690, pl. 1, fig. 2.

1992 Siphonosphaera magnisphaera ? Takahashi, part. Lazarus, p. 795, pl. 2, figs. 9-10; pl. 5, figs. 13-14, non figs. 11-12.

1999 Siphonosphaera arkys Su. - Tan \& Chen, p. 139, pl. 5 , fig. 41.

2001 Trisolenia sp. - De Wever et al., p. 170, Fig. 104.2.

Description. Shell spherical, exceptionally ellipsoidal with thin wall perforated by a small number (some 10-15 or more) of wide pores with margins prolonged outside in very short tubes. Surface of test covered with numerous and dense minuscule pits. These pits disappear on the tubes, their surface remaining smooth.

Dimensions: Diameter of shell 120-180 $\mu \mathrm{m}$.

Etymology. From the Latin brachys - short and siphontube, pipe.

Remarks. Siphonosphaera arkys Su resembles perfectly Siphonosphaera brachysiphonia Dumitrică (see Figure 1i-h) by its shape, number, shape and length of tubes and pitted surface of shell, and is undoubtedly a junior synonym of the Badenian species. These pits were considered pores by $\mathrm{Su}$, but they are certainly just a superficial ornamentation. The same species was illustrated by Abelmann (1990, pl. 1, fig. 2) as collosphaerid sp. A from the Middle Miocene of the Antarctic area (Maud Rise, Weddell Sea). A very close species to S. brachysiphonia Dumitrică is Siphonosphaera magnisphaera Takahashi, 1991 (not Lazarus 1992) by being spherical, by having pitted surface except the borders of pores, but differs from the Badenian species by being larger (having a 

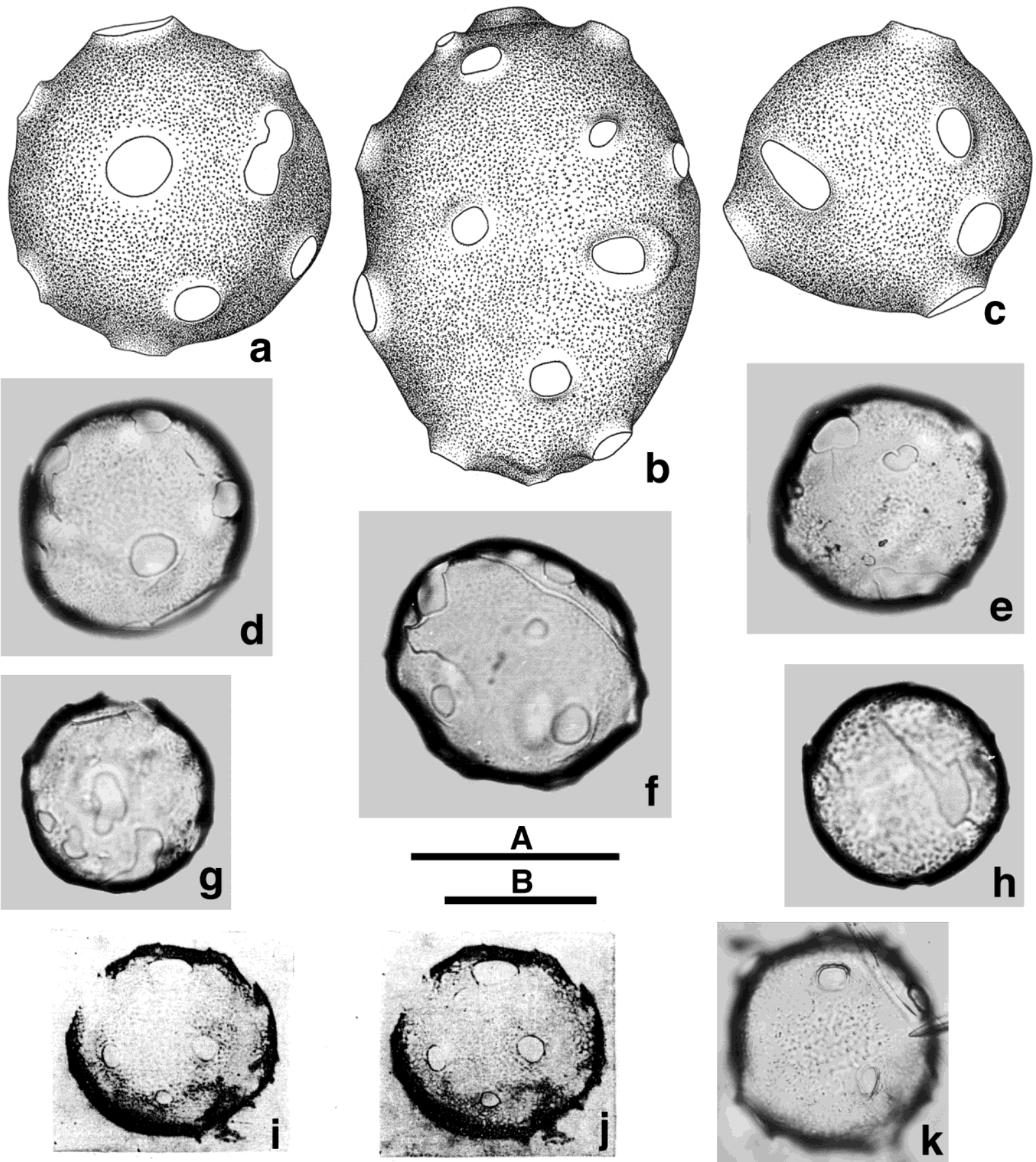

Fig. 1 a-h Siphonosphaera brachysiphonia Dumitrică, 1978. d holotype, original photo. Scale bar A (for drawings, a-c) $=100 \mu \mathrm{m}$, scale B (for figures in optical microscope) (d-h, k), all from sample 1315, Radiolarian Shale Formation, Păușești Otăsău, Getic Depression, Romania. i-j Siphonosphaera arkys Su, 1982, holotype; k Siphonosphaera brachysiphonia, specimen from ODP Leg 120, sample 751A-13H-CC, Middle Miocene, approximately 14.4 Ma, kindly provided by Dr. Johan Renaudie.

diameter of 190-197 $\mu \mathrm{m}$ ) and by having a much more perfect spherical shape. Under the same name Lazarus (1992) illustrated from Antarctic area (Kerguellen Plateau, ODP Leg 120) two morphotypes: a larger morphotypes (pl. 5, figs. 11, 12) and a smaller one (pl. 2, figs. 9, 10 and pl. 5, figs. 13, 14). The larger morphotype differs from $S$. magnisphaera Takahashi in having fewer and longer tubes, and the smaller ones in being smaller and having a less perfect spherical shape. The smaller morphotypes illustrated by Lazarus are rather similar to $S$. brachysiphonia and could be considered as belonging to it. The larger one should belong to a new species.
Anyway, all species discussed here seem to form a closely related group characterized by a rather similar morphology and especially by having a pitted surface. For more or less distinct morphologies we should take into account that they occur at different latitudes. The morphotypes (species) illustrated by Abelmann (1. cit.) and Lazarus (1. cit.) come from high south latitudes whereas the species described by Takahashi (1991 come from the tropical area of the Pacific Ocean $\left(15^{\circ} 21.1^{\prime} \mathrm{N} / 151^{\circ} 28.5^{\prime} \mathrm{W}\right)$. Accordingly, they could be characteristic of different latitudes. 
Occurrence. Until present the species Siphonosphaera brachysiphonia Dumitrică was recorded in the late middle Miocene of Romania (late Badenian), Antarctic area (Weddell Sea and Kerguellen Plateau), and Quaternary of China and Antarctic area. My German colleague Johan Renaudie who very kindly provided a photo of this species mentioned (in lit.) that he observed it in the middle and late Miocene of the ODP sites 689B, 748B and 751A from ca. 9 to $14 \mathrm{Ma}$. For Romania it is the only collosphaerid recorded in the Radiolarian Shale Formation, and this occurrence fit well in this interval because the Upper Badenian age of the Radiolarian Shale Formation corresponds to the lower Serravallian Mediterranean stage (13.8-12.8 Ma) (see Hohenegger et al., 2014 and Dumitrică, 2016 for detailed discussion). I know no record of this species in the Pliocene, but it should have existed in some places because the synonymy between the middle Miocene species and the Quaternary one is doubtless.

\section{DISCUSSION}

The occurrence of this species in the late middle Miocene (late Badenian) of Romania and Quaternary of China or Miocene of Antarctic area is not a surprise. It is an additional argument that the Central and Eastern Paratethys were not completely closed from the Tethys in the late middle Miocene and that at least at some intervals it had connections with the Indian Ocean and, through it, with the Pacific Ocean. The radiolarian and silicoflagellate assemblages of the Radiolarian Shale Formation prove plainly these connections (Dumitrică, 1978a, 1978b). Few species are restricted to it, as for example Distephanopsis bachmanni Dumitrică (Dumitrică, 1964, 1978a), among the silicoflagellates, whereas Distephanopsis stauracanthus (Ehrenberg), a cosmopolitan species with restricted biostratigraphic range and marker fossil for the D. stauracanthus Subzone of the Corbisema triacantha Zone (Martini, 1971, 1972) of middle Miocene in the Pacific and Indian Oceans (Desikachari \& Maheshwari, 1956; Bukry, 1981; Perch-Nielsen, 1985) is very frequent in the Radiolarian Shale Formation and permits a very good correlation with such oceans (Dumitrică et al., 1975).

About the connections with the Indian and Pacific oceans speak in fact the whole radiolarian and silicoflagellate assemblages of the Radiolarian Shale Formation and especially two samples: 1315 from the Tilvici Valley, village Păușești Otăsău, and $O M 54$ from Valea Sărată (Salted Valley), locality Ocnele Mari, both in the district Râmnicu Vâlcea and already mentioned in two previous papers (Dumitrică, 2016; 2017). Unlike the common lithology of the Radiolarian Shale Formation that consists of finely stratified argillaceous or marly-argillaceous deposits of black, grey or brown colour with some intercalations of tuffs suggesting an anoxic bottom, these two samples, that come from the same level, are represented by a bed of about $5 \mathrm{~cm}$ of indurated yellow marl full of big tests of Centrocubus cladostylus Haeckel, Diplospongus dendrophorus Mast, Lychnosphaera regina Haeckel and other radiolarians less frequent in the formation. Since the origination of species takes place usually in restricted areas it is possible that the Quaternary species: Siphonosphaera brachysiphonia Dumitrică, Diplospon- gus dendrophorus Mast, Lychnosphaera regina Haeckel and Centrocubus cladostylus Haeckel, frequent only in the two mentioned samples, from the same level, had their origin in Paratethys during the late Middle Miocene from where they migrated in the Indian Ocean through the eastern Anatolian seaway (Araks Strait) (Studencka et al, 1998; Rögl, 1999) and from it to the Pacific Ocean. Unfortunately we do not know exactly the first appearance datum (FAD) of these species. Anyway, these species and many others frequent in the two samples and the yellow colour of the sample suggest a good circulation between the Getic Depression and the Indian Ocean and well oxygenated bottom waters for a short interval of the Radiolarian Shale Formation. It is also most possible that all species occurring in this formation were immigrants in the Central Paratethys from the Indian Ocean as previously supposed (Dumitrică et al, 1975).

\section{ACKNOWLEDGEMENTS}

The author thanks the two reviewers Johan Renaudie (Museum für Naturkunde, Berlin, and Noritoshi Suzuki (Tohoku University, Sendai) for kindly reviewing the manuscript, for critical remarks and suggestions. A special thank is due to Johan Renaudie for providing a photo of a specimen of Siphonosphaera brachysiphonia from ODP Leg 120, (see Figure 1k), which is the oldest specimen of this species I know.

\section{REFERENCES}

Abelmann, A., 1990. Oligocene to Middle Miocene radiolarian stratigraphy of southern high latitudes from Leg 113, Sites 689 and 690, Maud Rise. in: (Barker, F.P., Kennett, J.P., et al. eds.) Proceedings of the Ocean Drilling Program, Scientific Results, vol. 113: 676- 708.

Bukry, D., 1981. Synthesis of Silicoflagellate stratigraphy for Maestrichtian to Quaternary marine sediment. Soc. Econ. Paleontol. Minerale. American Association of Petroleum Geologists, Special Publication, 32: 433-444.

Caulet, J.-P., O’Dogherty, L., Dumitrică, P., Suzuki, N., 2017. An up-to-date catalogue of Cenozoic genera and families: a review with illustrations of type species. Proceedings of Inter-Rad XV in Niigata 2017. Abstracts. Radiolaria Newsletter 40: 286-287.

Desikachari, T.V., Maheshwari, C.L., 1956. Fossil silicoflagellates from Colebrook and Nancoori Islands. Journal Indian Botanical Society, 35: 257-264 pl. 13, figs. 1-19.

De Wever, P., Dumitrica, P., Caulet, J.-P., Nigrini, C., Caridroit, M., 2001. Radiolarians in the Sedimentary Record. Gordon \& Breach Science Publishers, Amsterdam, $533 \mathrm{pp}$.

Dumitrică, P., 1967. Dictyocha bachmanni nov. sp. et considérations sur la lignée phylogénétique Dictyocha crux - D. stauracantha - D. bachmanni. Cahiers de Micropaléontologie, Série I, $\mathrm{N}^{\circ}$ 4: 1-6, pls. 1-2. Centre National de la Recherche Scientifique, Paris VII, Arch. Orig. Centre de Documentation C.N.R.S., $1967, \mathrm{~N}^{\circ} 435$. 
Dumitrică, P., 1974. Monografia radiolarilor din Romania. Ordinul Spumellaria în Miocen. 81 pp., 28 pls., Institutul Geologic, București.

Dumitrică, P., 1978a. Badenian silicoflagellates from Central Paratethys. In: E. Brestenská (ed.) Chronostratigraphie und Neostratotypen. Miozän der Zentralen Paratethys, Bd. 6, Miozän M4 - Badenien: 207230, VEDA, Bratislava.

Dumitrică, P., 1978b. Badenian Radiolaria from Central Paratethys. In: E. Brestenská (ed.) Chronostratigraphie und Neostratotypen. Miozän der Zentralen Paratethys, Bd. 6, Miozän M4 - Badenien: 231-261, VEDA, Bratislava.

Dumitrică, P., 1983. Evolution of Mesozoic and Cenozoic Centrocubidae (Radiolaria). Revue de Micropaléontologie, vol. 25, no. 4: 221-230.

Dumitrică, P., 2016. Middle Miocene (late Badenian) Phaeodaria from Romania. Acta Palaeontologica Romaniae, 12 (2): 3-20.

Dumitrică, P., 2017. Contribution to the knowledge of Entactinaria radiolarian family Rhizosphaeridae Haeckel and description of some new genera and species. Revue de Micropaléontologie, 60: 469-491.

Dumitrică, P., Gheța, N., Popescu, Gh., 1975. New data on the biostratigraphy and correlation of the Middle Miocene in the Carpathian area. Institutul de Geologie \& Geofizică, Dări de seamă, 61 (4): 65-84, pls. 1-9, Bucureşti.

Ehrenberg., C.G., 1875. Fortsetzung der mikropaleontologischen Studien als Gesammt-Uebersicht der mikroskopischen Paleontologie gleichartig analysirter Gebirgsarten der Erde, mit specieller Rücksicht auf den Polycystinen-Mergel von Barbados. Abhandlungen der Königlicher Akademie der Wissenschaften zu Berlin, Jahrg. 1875: 1-226, pls. 1-30.

Haeckel, E., 1881. Entwurf eines Radiolarien-Systems auf Grund von Studien der Challenger-Radiolarien. Jenaische Zeitschrift der Naturwissenschaften, 15 (new ser. vol. 8), no. 3: 418-472.
Hohenegger, J., Ćorić, S., Waigreich, M., 2014. Timing of the Middle Miocene Badenian Stage of the Central Paratethys. Geologica Carpathica 65 (1): 55-66.

Lazarus, D., 1992. Antarctic Neogene radiolarians from the Kerguelen Plateau, Legs 119 and 120. in: Wise, S.W., Jr., Schlich, R., et al. Proceedings of the Ocean Drilling Program, Scientific Results, vol. 120: 785809.

Martini, E., 1971. Neogene silicoflagellates from the Equatorial Pacific. In: Winterer, E.L. et al., 1971, Initial Reports of the Deep Sea Drilling Project, Washington, Government Printing Office, 7: 1693-1708.

Müller, J., 1858. Über die Thalassicollen, Polycystinen und Acanthometren des Mittelmeeres. Abh. Kgl. Akad. Wiss. Berlin, Jahrg. 1858: 1-62, pls. 1-11.

Perch-Nielsen, K., 1985. Silicoflagellates. In: (H.M. Bolli, J.B. Saunders, K. Perch-Nielsen eds.) Plankton stratigraphy. Cambridge University Press (Cambridge Earth Science Series): 811-846.

Rögl, F., 1999. Mediterranean and Paratethys. Facts and hypotheses of an Oligocene and Miocene paleogeography (short overview). Geologica Carpathica, 50 (4): 339-349.

Studencka, B., Gontsharova, I.A., Popov, S.Y., 1998. The bivalve faunas as a basis for reconstruction of the Middle Miocene history of the Paratethys. Acta Geologica Polonica, 48 (3): 285-342.

$\mathrm{Su}, \mathrm{X}$., 1982. Description of 11 new species of Radiolaria from the Xisha Islands, Guangdong Province, China. Oceanologia et Limnologia Sinica, 13 (3): 275-284, pls. 1-2.

Takahashi, K., 1991 - Radiolaria: Flux, ecology and taxonomy in the Pacific and Atlantic. Ocean Biocenosis Series 3: 1-301.

Tan, Zh., Chen, M., 1999. Offshore Radiolaria in China. Science Press, Beijing, China, 404 pp., 14 pls., 390 text-figs., 9 Tab. (in Chinese with English abstract). 